\title{
The Impact of Economic Policy Reforms on Labour and the Nigerian Civil Society: A Stakeholders' Dialectics
}

\author{
Sola Fajana \\ Professor, Department of Employment Relations and Human Resource Management, \\ Faculty of Management Sciences, University of Lagos, Akoka, Yaba, Lagos, NIGERIA.
}

\begin{abstract}
The objective of this paper is to examine the impact of current reforms on labour and the civil society in Nigeria. The targeted outcome of the reforms essentially is to reduce poverty and generally improve the lot of the people. It is therefore significant to examine the extent to which the reforms are affecting, positively or negatively, the Nigerian people. This paper therefore provides an overview of the extent to which stakeholders in the Nigerian project are variously affected by current economic reforms, their reactions and the ways in which future policy reforms should be approached. The paper relies on reviews of archival materials and focal interviews of relevant groups to provide insightful information. It was found that reactions have been largely impulsive, lacking coherent future follow-through actions to consolidate initial gains. It is now learnt from lessons of experience that reforms must be appropriate, timely but not impulsive, and well-articulated to achieve the targeted results. It is recommended that policy reforms should be jointly initiated, considered and driven by all constituents to the Nigerian project, to achieve a sense of ownership and high volume commitment.
\end{abstract}

Keywords: economic reforms, labour, civil society, poverty, strategic choice, Nigeria

\section{INTRODUCTION}

Reforms become necessary, expedient or even compulsive when existing structures and processes are visibly malfunctioning and or counterproductive. Oil-rich Nigeria, long hobbled by political instability, corruption, inadequate infrastructure, and poor macroeconomic management, is undertaking some reforms under successive administrations. Nigeria's former military rulers failed to diversify the economy away from its overdependence on the capitalintensive oil sector, which over the years provides $20 \%$ of GDP, 95\% of foreign exchange earnings, and about 65\% of budgetary revenues (Fajana, 2005b, NBS 2019). The largely subsistent agricultural sector has failed to keep up with high population volume of close to 200 million in 2019. With this figure, Nigeria is Africa's most populous country - and the country, once a large net exporter of food, now import food. Following the signing of an IMF stand-by agreement in August 2000, Nigeria received a debt-restructuring deal from the Paris Club and a $\$ 1$ billion credit from the IMF, both contingent on economic reforms. Nigeria pulled out of its IMF program in April 2002, after failing to meet spending and exchange rate targets, making it ineligible for additional debt forgiveness from the Paris Club. Later, the government began showing the political will to implement the market-oriented reforms urged by the IMF, such as to modernize the banking system, to curb inflation by blocking excessive wage demands, and to resolve regional disputes over the distribution of earnings from the oil industry. In 2003, the government began deregulating fuel prices, announced the privatization of the country's four oil refineries, and instituted the National Economic Empowerment Development Strategy, a domestically designed and run program modelled on the IMF's Poverty Reduction and Growth Facility for fiscal and monetary management. GDP rose strongly in 2005, based largely on increased oil exports and high global crude prices. In November 2005, Abuja won Paris Club approval for a historic debt-relief deal that by March 2006 should eliminate $\$ 30$ billion worth 
of Nigeria's total $\$ 37$ billion external debt. The deal first requires that Nigeria repay roughly $\$ 12$ billion in arrears to its bilateral creditors. Nigeria would then be allowed to buy back its remaining debt stock at a discount. The deal also commits Nigeria to more intensified IMF reviews.

In 2014, the GDP was rebased and the Nigerian economy shut up to the first position in Africa. There is so much growth but the economy has little to show for this at the level of distribution to its citizens, and poverty continues relentlessly. This phenomenon may have incensed the civil society with a sense of suspicion and lack of sincerity for government reforms, and the logistics of the stakeholders' reactions to government reforms.

The objective of this paper is to examine the impact of selected economic reforms on labour and the civil society in Nigeria. The targeted outcome of the reforms essentially is to reduce poverty and generally improve the lot of the people. It is however significant to examine the extent to which the reforms are achieving their set objectives. One critical way of judging the level of acceptance of these reforms is the dialectic reactions of the stakeholders, and the countervailing force of the State.

Archival records formed the source of information in this paper. Thus data from the Nigerian Bureau of Statistics, as well as credible international development agencies were reviewed. The illustrations were taken from published cases of protests by the labour and civil society organisations.

\section{DEMOGRAPHIC DIVERSITY OF THE NIGERIAN PEOPLE}

Nigeria is famous for her huge population of about 200 million people (Worldometers, 2019) the largest national population on the African continent. This population is made up of about 374 pure ethnic stocks. Three of them, Hausa, Ibo and Yoruba are the major groups and constitute over 40 per cent of the population. In fact, about 10 ethnic linguistic groups constitute more than $80 \%$ of the population: the other large groups are Tiv, Ibibio, Ijaw, Kanuri, Nupe, Gwari, Igala, Jukun, Idoma, Fulani, Edo, Urhobo and Ijaw. The gender divide of Nigeria's population, as indicated by the census in 1991, reflects an unusual imbalance in favour of male dominance; $51 \%$ male: $49 \%$ female (Fajana, 2000).

However, the more critical population indices concern:

- High growth rate $-3.2 \%$; this is affected by decreased infant mortality and high fertility.

- High school age population - over $47 \%$ are 15 years and below

- High child dependency ratio - one dependant to one worker for the working age group 25-65.

- Large work force - working age group 15-59 is over 40 per cent of the population.

Due to a massive expansion in the education sector in the last two decades, the coloration and quality of the Nigerian workforce has changed to include a large corps of highly trained personnel in mechanical, civil, electrical, electronics, chemical and petroleum engineering and biotechnics. There are in 2019, 43 Federal and 47 State Universities, some of them specialist Technology and Agriculture, as well as 75 private universities (NUC, 2019). In addition there are at least 30 Federal and State Polytechnics. Over 70,000 graduates in various disciplines are produced from these institutions every year. Disciplines, apart from pure sciences, engineering and technologies, include social sciences, business studies (management, banking and finance), architecture, environment and urban management studies. Also, a sizeable Nigerian population has been and is being trained outside the country, in some of the best colleges in the United States, Canada, United Kingdom, Germany, France, Russia, Japan and China. 
Every year, about 2,000 of these Nigerians return home to seek employment or accommodation within the economy. For the less skilled and unskilled labour, the country depends on the primary and secondary school systems whose annual enrolments are over 3.5 million and 1.5 million, respectively. It is evident therefore that the quantum of high-level skills and competencies have been increasing out of pace with the opportunities for employment generation.

The importance of the foregoing rich demographic diversity is the support reactions could muster from segments of society that feels left out in the distribution of state resources towards meeting their often varied and competing goals, and the latent fear that such sharing would be unfair, nepotistic, and ethnic interest serving.

\section{Students and Unemployed People}

Presently Nigeria has 59,761 primary schools and still needs 150,000 more, to meet the needs of its ever-growing population. Table 1 illustrates the volume of shortfall at respective level of the educational system in Nigeria.

Table 1: Pupil enrolment and shortfall: Basic and Post-Basic Education

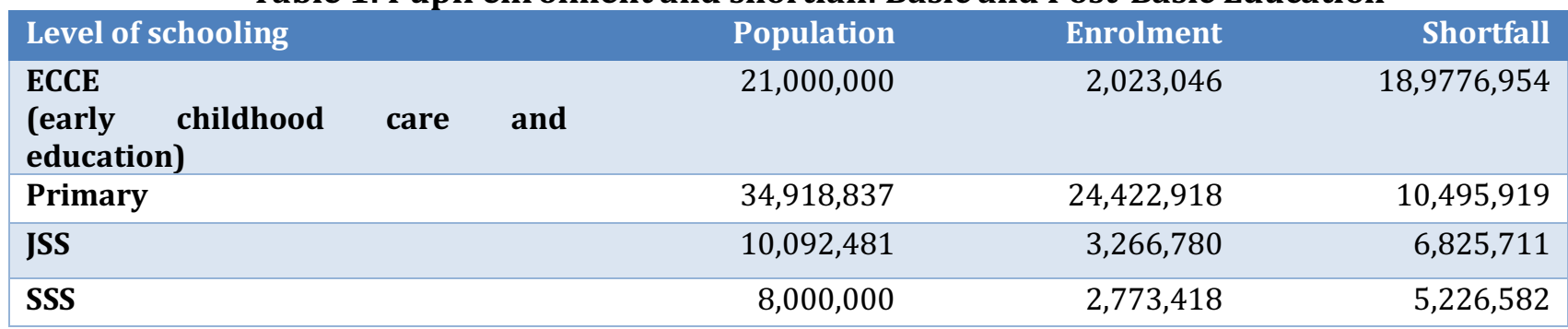

Source: Federal Ministry of Education, unpublished report (2010)

Table 2: Registration of Universities in Nigeria: 1980-2018

\begin{tabular}{|llccccc|}
\hline 1. & Public universities & $\mathbf{1 9 8 0}$ & $\mathbf{1 9 9 0}$ & $\mathbf{2 0 0 0}$ & $\mathbf{2 0 1 0}$ & $\mathbf{2 0 1 8}$ \\
\hline 2. & State universities & 14 & 19 & 25 & 27 & 43 \\
\hline 3. & Private universities & 2 & 6 & 17 & 34 & 47 \\
\hline & Total & & & 3 & 40 & 75 \\
\hline
\end{tabular}

Source: Compiled from data available at the NUC website

These statistics illustrate the fact that no National Vision of any country's development can be meaningful and properly driven unless that country knows first where it is presently, before projecting where it wants to be. In the case of Nigeria, without knowing the number of additional primary schools Nigeria needs and the number of children who are supposed to be in school that are not yet in school, it is trite to attempt an assessment of the progress towards the sustainable development goals (SDGs).

One gratifying thing to note is that the gap between research (knowledge) and public policy making is narrowing (Uzochukwu, et. al, 2016; and Uneke et. al 2017), and as such knowledgebased policies become more prospective. Elsewhere especially in the West, government releases from time to time information on how many jobs it has created. Such feedback evidence have been inadequate in Nigeria.

The policy of the federal government on Consolidation of Tertiary Institutions (Vanguard, Thursday, November 16, 2006) is of particular note. During the administration of President Obasanjo, it was revealed that both the Yaba College of Technology and the Kaduna Polytechnic 
were to be converted into universities. According to the president, a Presidential Technical Committee is currently looking at the implementation of the Consolidation of Polytechnics and Colleges of Education into campuses of neighbouring Universities (Saturday Champion Newspapers, November 18, 2006). In 2019, the conversion plan to make the designated polytechnics into universities is yet to be consummately implemented.

The consolidation policy was expected to open up 500,000 admission spaces in Nigeria. Although the details of the tertiary education reforms are yet to be finalized, even far away in 2019 , it is important to recognize that what has been revealed so far is a positive fundamental shift and step in the quest for the massification of higher education in Nigeria. There is no doubt that idle and frustrated young boys and girls need the 500,000 spaces that the consolidation policy would open up to keep them productively busy. However, fear was expressed in some quarters that this policy might sacrifice academic standards and expected minimum tolerable quality of infrastructural facilities in such institutions because of the pressure of time on the government and its desire to leave a worthy legacy. Notwithstanding the excellent intention of this policy, a lot more could have been achieved if the change was processed through reasonable caution via a pilot study in a similar institution,, thus avoiding an unintended impulsive label.

So far, the granting of licenses to private universities has been driven by the need to maintain some minimum and acceptable level of standards. Therefore, one does not expect that any new degree-awarding public institution should possess less than what private universities were required to have during their approval and licensing stage. But since there is a Presidential Technical Committee working on the consolidation policy, one expects that the system should come out more strengthened than weakened.

These reforms have had the following effects on students and unemployed people: a large number of secondary school leavers who have remained unemployed on account of long periods of unemployment experienced by their predecessors in the labour market seemed to have dampened the morale of students for high quality grades. What is more, a gradual crumbling of the educational system had in the previous years caused similar damage to the morale of their teachers. Consequently, inadequate quality time on task is manifested, students have a large idle time on their hands, and overall the quality of graduates produced continues on the decline. This trend could be reversed in the future if the on-going consolidation is implemented religiously but cautiously. More devastatingly, the Obasanjo-led reforms of the education sector seemed to have been ingloriously discontinued by the succeeding administrations. Thus, reforms that were supposed to be well conceived suffered from stop-go policy disconnects between successive administrations in Nigeria.

\section{Workers, Trade Unions and the Civil Society}

Nigerian workers strived to weather the storm of the recession of the late 1980s, even though the incident affected membership of trade unions adversely on account of recorded job losses. Trade union membership recovered a little at the turn of the millennium. Thus, there was no major incident until 2005. In the immediate previous years, the labour movement carried several protests to the federal government on the issue of continued and sustained increases in the prices of petroleum products. Against the backdrop of the criticality of this source of energy for industrial and human development, 


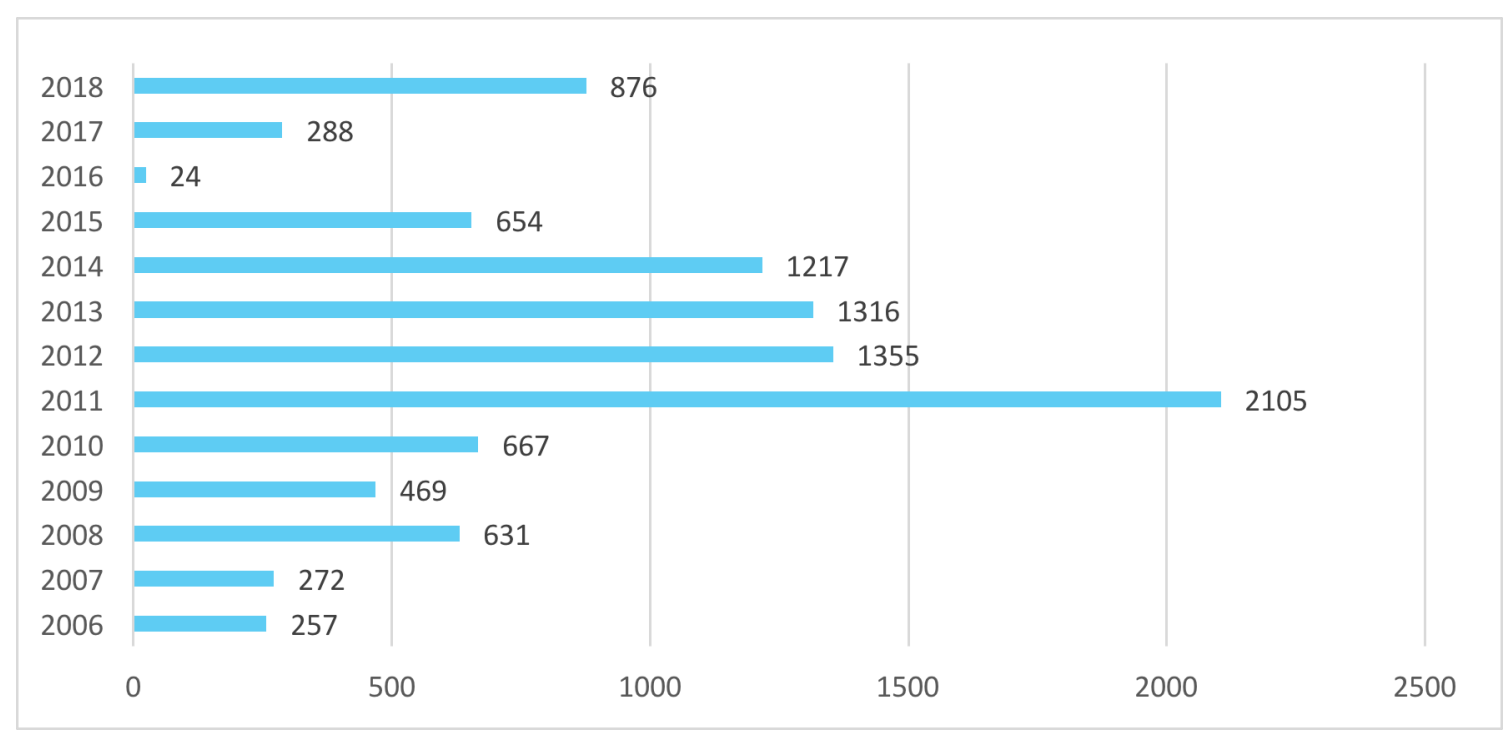

Figure 1: Fuel Subsidy (N’billion) 2006 - 2018

Source: The data used to produce this chart is available at -

https://www.dailytrust.com.ng/nigeria-spent-n9tr-on-fuel-subsidy-in-10-years-pppra.html

the Nigeria Labour Congress under the leadership of Comrade Adams Oshiomhole led the civil societies to resist the actions of government. These attempts were somewhat successful as government had to reduce advertised prices at least marginally on each occasion (See Table 2). It is suspected and widely criticised that the reforms that followed were aimed at crippling the efforts of the Congress to enable government have a free day at determining fuel prices through deregulation.

In 2005, the government ostensibly in its bid to democratise the labour movement along more ILO-compliant policies, came up with revisions that enabled labour centres other than the NLC to register. Thus the senior staff associations received legal backing for their confederation. Two of such senior staff federations registered: the Trade Union Congress of Nigeria (TUC) and the Congress of Free Trade Unions of Nigeria (CFTU). 


\begin{tabular}{|c|c|c|c|}
\hline DATE & PRICE PER LITRE & REGIME & INCREASE (\%) \\
\hline Jan 1966 - Sept 1978 & 8.5 kobo & $\begin{array}{l}\text { Gen Aguiyi Ironsi } \\
\text { Gen Yakubu Gowon } \\
\text { Gen Murtala Mohammed }\end{array}$ & \\
\hline October 1, 1978 & 15.5 kobo & Gen Olusegun Obasanjo & 73.9 \\
\hline April 20, 1982 & 20 kobo & Alhaji Shehu Shagari & 31.0 \\
\hline March 31, 1986 & 39.5 kobo & Gen Ibrahim Babangida & 97.5 \\
\hline April 10, 1988 & 42 kobo & Gen Ibrahim Babangida & 6.0 \\
\hline January 1, 1989 & $\begin{array}{l}40 \text { kobo for commercial, } \\
60 \text { kobo for private }\end{array}$ & Gen Ibrahim Babangida & 43.0 \\
\hline December 19, 1989 & 60 kobo for all vehicles & Gen Ibrahim Babangida & 43.0 \\
\hline March 6, 1991 & 70 kobo & Gen Ibrahim Babangida & 16.6 \\
\hline Nov. 8, 1993 & N5.0 & Chief Ernest Shonekan & 614.0 \\
\hline Nov. 22, 1993 & N3.25 & Gen Sanni Abacha & -35.0 \\
\hline October 2, 1994 & N15.00 & Gen Sanni Abacha & 361.5 \\
\hline October 4, 1994 & N11.00 & Gen Sanni Abacha & -26.67 \\
\hline Dec. 20,1998 & N25.00 & Gen Abdulsalami Abubakar & 127.0 \\
\hline January 6, 1999 & N20.00 & Gen Abdulsalami Abubakar & -20.0 \\
\hline June 1, 2000 & N30.00 & Chief Olusegun Obasanjo & 50.0 \\
\hline June 8,2000 & N25.00 & Chief Olusegun Obasanjo & -16.67 \\
\hline June 13,2000 & N22.00 & Chief Olusegun Obasanjo & -12.0 \\
\hline January 1, 2002 & N26.00 & Chief Olusegun Obasanjo & 18.2 \\
\hline June 20,2003 & $\mathrm{~N} 40.00$ & Chief Olusegun Obasanjo & 53.0 \\
\hline July 9, 2003 & N34.00 & Chief Olusegun Obasanjo & -2.40 \\
\hline October 1, 2003 & N38.50 \& N42.00 & Chief Olusegun Obasanjo & 23.53 \\
\hline May 29, 2004 & N49.90 & Chief Olusegun Obasanjo & 16.67 \\
\hline Sept. 2004 & N53.00 & Chief Olusegun Obasanjo & 8.16 \\
\hline Sept 2005 & N65.00 & Chief Olusegun Obasanjo & 22.64 \\
\hline 2007 & N75.00 & Chief Olusegun Obasanjo & 15.38 \\
\hline 2007 & N65.00 & Shehu Yaradua & -13.33 \\
\hline 2012 & $\mathrm{~N} 141.00$ & Goodluck Jonathan & 116.92 \\
\hline 2012 & N97 & Goodluck Jonathan & -31.20 \\
\hline 2015 & N145 & Muhamadu Buhari & 49.48 \\
\hline
\end{tabular}

\section{Source: Adapted and updated from Fajana (2005b)}

The Nigerian government has consistently hedged the right of Nigerian workers to strike. Some of the relevant legislations are in the Trade Disputes Acts 1969, 1976, and 1996. The Trade Unions (Amendment) Decree of 1996, makes check-off payments conditional on a "no strike" clause during the lifetime of a collective agreement. This clause stipulates that employers will not remit union checkoff dues to the union office unless a union member agrees to a 'no strike' clause in the collective agreements. Trade unions must also give 15 days' notice for a planned strike.

Strikes in essential services, including the oil and gas sector, are forbidden in Nigeria, as confirmed again in the 2005 law. First, the law clearly bans industrial actions in the oil sector, and Section 9 of the Trade Dispute (Essential Services) Act, 1976 lists the economic sectors which fall within "essential service". Subsection (b) states that "any service established, provided or maintained by the Government of the Federation or of a State, by a Local Government Council or any municipal or statutory authority, or by private enterprise (i) for, or in connection with, the supply of electricity, power or water, or of fuel of any kind." The preface in the Act also states that the Act was to "empower the President to proscribe any trade union or association the members of which are employed in any essential service if such Union or Association has been engaged in industrial unrest or acts calculated to disrupt the smooth 
running of any essential service, or has, where applicable, wilfully failed to comply with the procedure specified in the Trade Disputes Act in relation to the reporting of the settlement of trade disputes."

Second, the Government of Nigeria declares any trade union activities illegal in the name of wrongful politically-motivated activities. For example, (1) a strike at Shell-BP and Allied Workers Union in October 1977 (Proscription Order No. 2) and (2) a strike at the Pan Ocean Branch of the Consolidated Petroleum, Chemical and General Workers Union of Nigeria in November 1977 (Proscription Order No. 3). Between 1993 and 1994, many strikes staged by NUPENG and PENGASSAN were claimed as being illegal because they were politically instigated in the aftermath of the annulled Nigerian national presidential election believed to have been won by M K O Abiola,

In October 2003, a new law was proposed to the National Assembly to amend the Trade Union (Amendment) Act. After some revisions the law came into effect in March 2005. The law ends automatic trade union membership. The legislation makes union membership voluntary and introduces a general strike ban. Chapter 432 of the Trade Disputes Act, Laws of the Federation of Nigeria, 1990, compels trade unions to follow strict procedures on arbitration, before embarking upon a strike, and a simple majority of registered members vote in favour of strike action.

In addition, legislation also makes it difficult for workers to go on strike by demanding that they meet certain procedural requirements. For example, Section 17 (a \& b), Paragraph 14 of the Trade Union Act states that union rules must include a provision which forbids trade union members to take part in any strike unless there was a majority vote in favour of the action.

Provisions of the 2005 law included: the prohibition of strikes in services that were regarded as essential; in non-essential services, strikes are now subjected to the taking of a strike ballot among the members of such unions; strikes can only occur after the due process have been exhausted and for disputes of rights (violation, non-implementation of collective agreements). Where the issues are over disputes of interest (fresh issues that are being processed for negotiation), strikes are prohibited.

According to the International Confederation of Free Trade Unions (ICFTU), many strikes took place in 2003 and 2004, over increasing oil prices and the proposed amendment to the Trade Union (Amendment) Act. In June 2003, the government announced plans to increase oil prices by 50 per cent. During the ensuing general strike 19 trade unionists were killed by police violence and shooting. Six trade unionists that were arrested in October 2003 were severely beaten up in prison. During 2004, several strikes were planned by the NLC against the hike in oil prices, but the High Court issued injunctions against these strikes and, in September, ruled such strikes illegal on the ground that they do not concern an industrial dispute. In June 2004, armed police descended on NLC headquarters during a general strike against an increase in oil prices. One trade unionist was shot dead, another was injured, and several arrests took place. A peaceful strike in September 2004, protesting against 18 months wage and pension arrears, was responded to with teargas and police attacks. The NLC president was arrested at gunpoint after the announcement of a four-day general strike with the aim of reversing petrol price rises. Five other trade unions were arrested that day as well. During the 11 October 2004 general strike a 12-year-old boy and a man were killed by police firing on protesters, and mass arrests took place. 
There was a surprise strategy shift in the reactions of organised labour during the September 2005 price hike. As the legal existence of the unregistered NLC hanged in the unknown, and the acceptability of strikes was waning, a new strategy was called for. Thus, rather than the characteristic strike actions which ended within four days without definite agreements, the civil society led by the NLC opted for mass rallies held at various times in different locations of the country. This proved somewhat effective. Whether this pragmatic strategy would enjoy continued adoption in the future is to be seen as the unavoidable struggle between organised labour and a government avowedly committed to globalisation and deregulation is expected to persist.

\section{The Multinational Employer}

Employers categories in Nigeria include the locally and foreign owned corporations, state governments and their corporations and private enterprises of various sizes and nationality. This typology underestimate the extent of foreign control of the Nigerian economy because some indigenous businessmen 'front' for foreigners, and also Nigerian executives of multinationals, who are still largely sympathetic to the cause of their foreign benefactors. Besides, there is the tendency for multinational employees to act in ways that are loyal to their employers having imbibed organisational sub-culture and training typical of all multinationals. Examining the structure of foreign capital in Nigeria, it was revealed that the sources of foreign direct investment are varied and changing over time. In 1973 for instance, 44.2 per cent of total foreign direct investment are attributable to the United Kingdom nationals alone; this figure had shifted to 29.0 per cent in 1981. The share of Japanese firms had increased from an unspecified but insignificant figure in 1973 to N98.1 million in 1981; whereas the investments from the USA have declined from N384.0 million (29.2 per cent) in 1973 to 139.5 (5.21 per cent) in 1981 (Bierstecker 1987). With the increased opening up of the economy, the size of multinational capital has continued to increase over time in Nigeria.

In 2018, the total value of capital importation into Nigeria stood at $\$ 2,140.08$ million in the fourth quarter. This represents a decrease of 25.05\% compared to Q3 2018 and 60.24\% decrease compared to the fourth quarter of 2017. Similarly, the total value of capital importation into Nigeria stood at $\$ 16,812.47$ million in 2018 compared to $\$ 12,228.57$ million capital imported in 2017. This represents 37.49\% growth YoY (NBS, 2019).

Technology choice and employment generation by multinational enterprises in developing countries have been the research focus of several contributors on the socio-economics of development (Akinsanya, 1984). The consensus has largely been that MNCs adopt capital intensive operational techniques and therefore contribute employment somewhat less than their proportionate investments.

Does the particular technology chosen by the subsidiary of a multinational enterprise in a developing country have an impact on the employment it provides? How does the cost of local labor and/or government policies influence these technology choices? Is there scope for adapting the technologies chosen to local conditions, in particular for making them more labor intensive?

It is found that within the context of globalisation, technology choice by subsidiaries of MNCs is necessarily constrained by competitive advantage and the quest for quality product and services. Consequently global trends of technology adoption necessarily diffuses to give subsidiaries some kind of compulsion irrespective of the labour situation in the host country. This has been the experience in Nigeria. As the economy was made much more open to foreign 
competition, for example by joining the WTO, liberalization of expatriate quotas and other such reforms, foreign employers responded expectedly by taking advantage of the benefits so offered. Hence, in the communications, oil and manufacturing sectors, employers increased the size of foreign employees even when there were local citizens with the appropriate and available skills. The policy of expatriate quota and enactment of the Local Contents policy in 2010 are expected to do some corrective to the downside of the growth of multinationals and their technology-biased expansion paths.

\section{The Informal Sector Employer}

The Small and Medium Enterprise (SME) sector has the highest potential for solving Nigeria's unemployment and poverty problems. The Vocational Education and Training (VET) system could prepare graduates to gain employment in the SME sector, or become entrepreneurs. However, training systems in developing countries generally, and in Africa in particular, are inadequate in supporting those seeking work or self-employment, and need to improve their relevance in order to effectively address this issue.

Thus, it is reasonable to explore the extent to which skills and education provided by VET institutions in Nigeria are relevant and adequate to meet the needs of the SME sector. Issues and constraints are faced by graduates of the VET system and the SME sector and government's efforts must be directed at tackling stubborn unemployment and poverty rates.

The Nigerian formal VET system includes government polytechnics and technical schools and the National Board for Technical and Business Education (NBTE), while the informal system works mainly through apprenticeships. Both of these systems face several problems.

In the formal system the problem is with resources and their management. The community generally has a poor opinion of vocational trade and graduates of the VET system are not employed readily. Those who work in this system do not appreciate the significance of the private sector in general and SMEs in particular. SMEs are usually the prospective employers of graduates from the VET system. But they are not involved in the design and delivery of VET programmes and this contradicts the claim by VET institutions that SMEs and employers are consulted on such issues.

The problems of the informal sector are inadequate support from government and its agencies as well as the low profile and image of the sector. Researchers (Ojo, 1995) also found that: There is high unemployment amongst graduates of polytechnics and technical colleges especially in the semi-urban centres.

- A new reform agenda for the Nigerian VET system has been initiated. This is based on the philosophy that VET should include educational institutions that produce graduates who are able to find jobs based on their technical and entrepreneurial skills and education.

- Reform of the VET system includes creation of more VET institutions, emphasis on selfemployment, improving the image of the system, accreditation of skills, training new teachers, reforming the curriculum to suit the needs of the people, etc.

- SMEs do not seem to recognise the significance of informal networks and relationships cultivated through trust and how its absence is causing major problems such as crime, loss of customers and the operation and development of the sector in general.

It is expected that the enactment of the Local Content Act in 2010 will significantly increase the access of prospective local entrepreneurs to business project opportunities. 


\section{ECONOMIC POLICY REFORMS AND THE CHANGING CHARACTER OF INDUSTRIAL} CONFLICTS

This section presents a selection of some of the reforms that have been introduced by the Nigerian State. Obviously, a new trend of conflict seems to have emerged, arising from the negative unanticipated reactions of the stakeholders. Some of these reforms have had a positive impact which would need to be strengthened in the future. But tackling the negative reactions would seem to be more urgent. The evolving trend of opposing and resisting by stakeholders is likely to be sustained so long as the people continue to be traumatized by some of the adopted reform policies. 


\section{Table 4: A Medley of Reforms}

$\begin{aligned} \text { S. NO } & \text { REFORMS WITH DATES } \\ 1 . & \text { PRIVATIZATION, } \\ & \text { LIBERALIZATION AND } \\ & \text { DE-REGULATION } \\ & \text { POLICY (2005) }\end{aligned}$

\begin{tabular}{l|l}
2. & LABOUR REFORMS \\
(2005) AND PENSION \\
REFORMS $(2004,2014)$
\end{tabular}

\section{COMMENTS}

Fuel shortages seem to have abated tremendously, but fuel subsidy which is corruption-flavoured continues into 2019. Although fuel is available in the late 2010s, inflation is skyrocketing, pump prices are on the increase because crude prices are soaring and reaching an all-time high. The spiralling multiplier effect is excruciating. Manufacturers are grunting under the yoke of increased cost of production, workers in the private sector are being retrenched in large numbers, while in the Oil and Gas industry, declaration of redundancies have become a daily occurrence. Government and enlightened watchers of the trend would not expect that crude prices could not remain stable.

The Labour Reforms were intended to promote labour democracy. Democratization of Labour should be balanced with the sanctity of the labour process. If however government is sincere about Labour democratization, then it has to follow democratic tenets. Pension Reforms have been much more facilitative of the fortunes of the capital market than with the welfare and compensation certainties which should have been of more interest to labour as a stakeholder.

\section{BANK REFORMS $(2004$, 2010)}

Bank consolidation (2004) was expected to lead to better access to more investible funds available at the bank vaults. Feared job loss which was promised would not happen in the pre-consolidation periods are now being recorded with impunity. The insurance sub-sector is also beginning to have a taste of consolidation and creatively venture into normal banking/investment products and services. The CBN also rolled out of number of system-protective measures in response to the global financial crises which effects heightened about 2008.

\section{EDUCATIONAL REFORMS (on going)}

\section{EXPATRIATE QUOTA REFORM (2015)}

\section{LOCAL CONTENT REFORMS (2010)}

\section{PUBLIC SERVICE REFORM (from 1999)}

\section{ENERGY SECTOR REFORM (On-going).}

The decision to restructure educational institutions along the 6334 system seemed to be a welcome one judging from the demands for the available forms of education by Nigerians. Caution must of course be taken to ensure inclusiveness of the restructure process as well as the human resource and industrial relations implications.

Through the instrumentality of the Immigration Act 2015, the government, in its quest for transfer of specialized skills and knowledge to Nigerians, has made provision for employment of highly skilled foreigners through the issuance of Expatriate Quota (EQ) approvals. The oil and gas industry, among others, is infested with unqualified expatriates. Apart from not adding value to Nigeria's operations, it is an indirect way of reducing unemployment abroad and compounding Nigeria's own unemployment situation. It insults our collective intelligence, and it portrays our agencies of gross inability to protect our citizens from exploitation. There are instances where expatriate young school leavers who are equivalent of NYSC are made supervisors. The implications of this are numerous.

Against the backdrop of poverty, corruption, kidnapping, unemployment, stealing, terrorism, militancy, and armed robbery amongst others, the Government of Nigeria, under the leadership of President Goodluck Ebele Jonathan (GCFR), in March 2010 signed into law the Nigerian Local Content Act which aimed at promoting industrialization of the nation's oil and gas industries and thereby improving the economic and social well-being of citizens engaged in the industries.

The focus of these reforms is the core civil service, as well as the reform agenda because of the place of these agencies in the direct provision of services to the public. In the particular case of parastatals, they have also embarked upon some reforms with either institutional or sectoral focus. These have been achieved in varying degrees of success. The Federal Government about 2004 launched a wholesale reform of all such agencies. Government has therefore issued the Generic Guidelines for the Reform of Parastatals.

Sequel to shortfalls in the generation and distribution sectors of the electricity value chain, government unbundled the old government owned electricity authority, the PHCN to create separate privatised units for generation 
(GENCO), distribution (DISCOs), and a public-owned regulatory agency (Nigeria Electricity Regulatory Commission, NERC). Notwithstanding the lofty ideals inherent in this reform, the cost of electricity for domestic and industrial use has remained uncomfortably high. The metering arrangement have not been without challenges arising from artificial scarcity and corruption.

Sources: (1) Adapted from Brown Ogbeifun, Reform and the People, PENGASSAN website (2) Nigeria. Public Service Reform: Generic Guidelines for the Reform of Parastatals, Issued by the Bureau of Public Reforms, The Presidency.

It is instructive to note that these reforms were well intended as poverty alleviators. As illustrated in Figure 2, in the periods preceding the reforms, there were poverty, misery, frustrations, unemployment, inflation, political and economic uncertainties, corruption and ailing public enterprises. However the policy reform process and outcome have often generated conflicts which are manifested at both tactical and strategic levels. It is expected that lessons derived from these actions would help all the actors to forge better management of reforms in the future. In the next section, the reactions of the stakeholders are attempted, using the lens of a dynamic idealized model designed by the author.

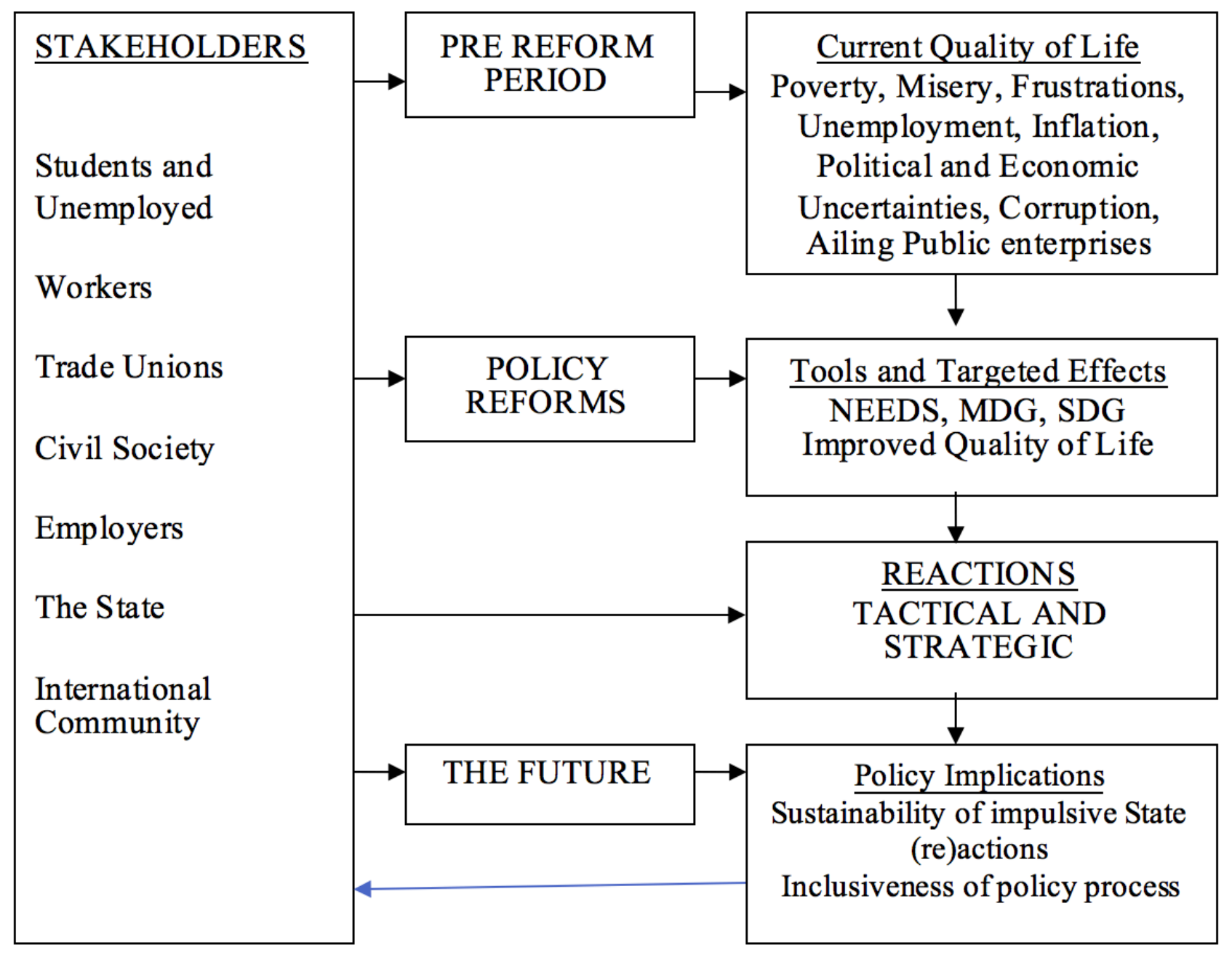

Figure 2: An Idealized Model of Reactions to Economic Reform Policies by the Stakeholders in Nigeria's Economy and Society Source: Adapted from Fajana (2008) Unpublished paper 


\section{REACTIONS OF THE STAKEHOLDERS}

The conceptual differentiation between tactics and strategies is requisite here in the structuring of responses by the stakeholders. Tactics are defined as short-term ad-hoc measures aimed at solving problems, whereas strategies take a longer-term and visionary view of problems and provide concerted solutions. Both response types are exemplified on both labour and State sides.

Research evidence has shown that workers and the civil society are more likely to take up conflictual matters with the State as tactical rather than the strategic modes. In this section, the dialectic model of conflict resolution, previously applied to labour-management relations (Fajana, 1999) is here adapted to illustrate the relationships between the state and other stakeholders; especially, organized labour.

Consider workers' response to State's actions in the workplace as shown in Figure 3. Starting with workers' response does not in any way suggest that the state is the aggressor in industry; we could just as well have started with state's response to the accusations that are sometimes levied against workers' 'irresponsible behaviour'.

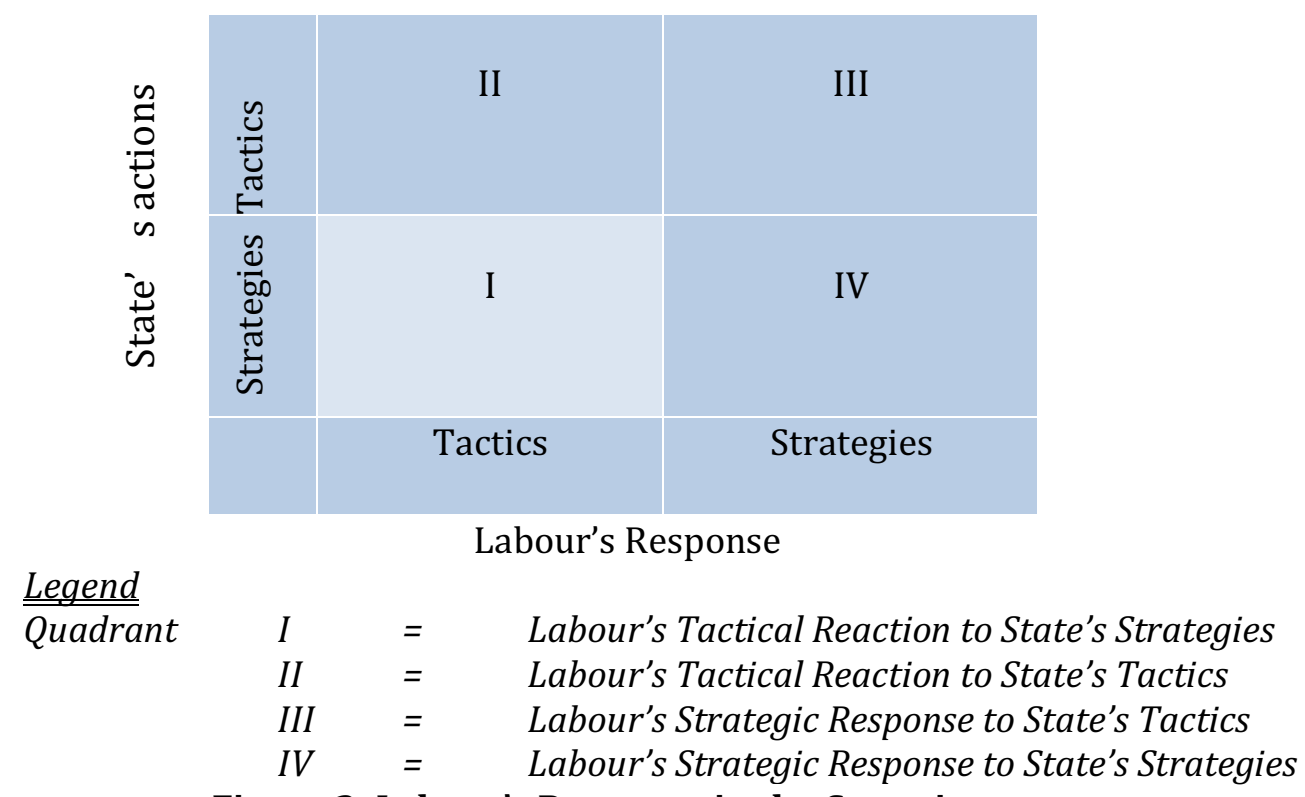

Figure 3: Labour's Response in the Cartesian space

However, this distinction may become blurred in practice as issues filed for a single dispute tend to be multiple (demands are often loaded) and unions may adopt different tactics and strategies at resolving specific items on the agenda. The distinction could also become blurred if the differentiation in the time dimension is relaxed between the short term and the long term, because the long term; it could be split into smaller tactical short-term horizons.

Each axis is subdivided into tactics and strategies; the thin lines serve to emphasise the fluidity in the differentiation between tactics and strategies. Thus the entire space is split into four quadrants.

In the first quadrant, tactical reactions of labour to the strategic behaviour of the State are placed. This is exemplified in increasing short term unexpected actions by workers in reaction to alienating direct controls or filibustering strategies of the State at the negotiation table. With regards to the current reforms, the NLC in 2005 changed tactics to tackling the State's unrepentant increase of prices of petroleum products. When it became obvious that incessant strikes were no longer popular among the civil society, the choice of rallies nationwide was 
preferred. The 6334 educational policy took a long time to strategically outline by the Government of Nigeria, but the stakeholders tactically frustrated it by their disapproval of aspect of terminating at 3-year programmes at technical colleges in place of senior secondary school (SSS), and eventually preferring instead movement into universities after the SSS class. The anti-strike laws took long concerting years to enact, but it was usually met by spontaneous workers actions, and the no work - no pay regulation is often rendered effectively impotent.

In the case of tertiary educational reforms, which had been found to be incoherent and contradictory since the 1990s, the reaction of the Academic Staff Union of Universities had been to place advertorials in newspapers and seek the collaboration of the media to popularise Union's objections. This was seen as the least that the Union could tactically do to counter the long term strategy of the State.

Responses in the second quadrant are workers' short term reactions to State's short-term actions. For instance calling a press conference or inviting the media for 'breaking news' are often tactically deployed by workers. The foregoing may be a reaction to high handedness and temporary insensitivity of the State as illustrated by delaying tactics when labour is willing and ready for negotiation, or the short term deployment of state police and killing of striking workers or protesting civil society. These actions, which are prevalent in ASUU-FGN negotiations are short-term for both parties because they are largely infeasible in the longerrun as previous experience would have shown.

In the third quadrant, labour embarks upon a long-term measure to counter State's ad-hoc actions. This is possibly best illustrated in unionisation and capacity building and human development efforts taken by organised labour to properly prepare for the tactical/short term surprises of the State. This is perhaps the foremost theory to explain the emergence of trade unions (Anderson, 1967). Unionism is considered as the inevitable reaction to the inability of individual workers to counter the actions of the employers (in the present case, the State). At those initial times, States openly expressed policy and executive bias in favour of employers, who in return paid absurdly low wages, insisted on long hours of work and ad-hoc dismissal of employees who express the slightest signs of discontent (Braverman, 1974).

Quadrant four represents the deployment of long-term action in reaction to the State's longterm measures. This may be illustrated by State invocation of ILO standards whenever it suits the purpose of the State. This is a long-term or strategic practice which tends to protect State interests. The motif of initiating the trade union reform towards democratisation was largely strategic. It was aimed at creating sustainable peace by assisting the trade unions to promote self-governing ideals in their internal management.

The above consideration pertains to response of labour that are mostly tactical. Even the strike which is the most lethal weapon of workers is in most cases tactically rather than strategically deployed. With the preference for wildcat (Gouldner, 1954) forms, the strike is seldom well and properly notified to the State long enough to frustrate the State from having sufficient time to formulate appropriate actions to counter the efforts of workers. Springing up surprises as in wildcat strikes is expected to yield better results because of costs inflicted on the State that cannot be immediately minimised or avoided.

The above schematisation can also be used to illustrate the response of employers to actions instigated by the workers (See Figure 4). 


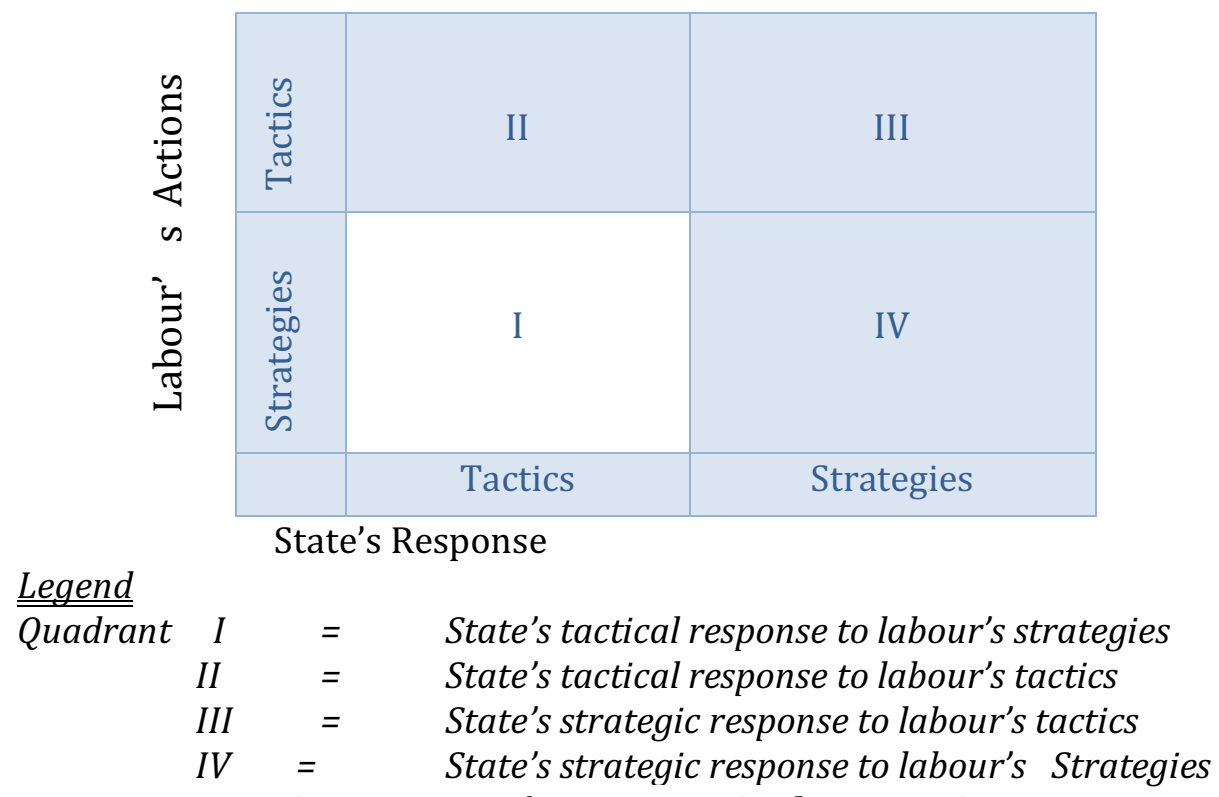

Figure 4: State's Response in the Cartesian Space

The first quadrant represents cases where the State is able to use tactical methods to counter labour's long-drawn out plan. For instance, such tactics as sweetheart agreements between the labour leadership and the executive (this is often feared, but may be a ruse) may frustrate other concerted plans the workers are exhibiting. Such "unfair labour practices" have often caused the untimely withering away (Hyman, 1972) of labour's actions that took so long to conceive and execute. Other examples are found in avoidance tactics when renegotiation is due or when it is time for the review of an existing agreement. The entrenchment of the review clause in an existing collective agreement may be considered as a long term strategy of the union to ensure that the employer does not continue to insist on rates that are contained in the provisions of previous agreement as such rates may have become irrelevant because of inflation. However, the 25 per cent indexed pay rise secured by the NLC about 2001 was never honoured by the Government. Similarly, the five yearly review of minimum wage strategically secured by labour was never implemented faithfully by the government. For instance, whereas a review was due in 2016, it tactically did not start until 2017, concluded in 2018, and had not been implemented in July 2019 !

In the State's second quadrant, tactical actions are deployed to counter labour's tactical measures. For instance, in countries where the strike is a mere tactic (because it is poorly organised), the State may simply deploy armed troops to dislodge striking workers. Some strikes in Nigeria in particular are tactical rather than strategic choices. Thus, it is possible for the State having had a foreknowledge of the impending strike from worker-rank informants to frustrate the actions by simply locking out workers and obtaining police protection before workers embarked on the action. In effect, the employer would effectively avoid serious damages and hurt. In other cases, the State invites armed forces to 'discipline' striking workers; or hired strike-breakers temporarily (example, Margaret Thatcher vs. Royal Mail, 1988).

In the case of anti-privatisation protests, workers grievances were centred on feared job insecurity and uncertainties about the willingness of new employers to settle their pension expectations. The Nigerian state officials, both executive and legislative, simply addressed the demonstrators openly with the assurance that their grievances have been heard and would be acted upon. All these are short-term measures that may be used to minimise the negative effects of labour's short-term actions and to render such short-term actions ineffective. 
The State's third quadrant represents cases where long-term measures are taken to counter labour occasional or short-term outbursts. Here unitary orientation, State incorporation and loyalty socialisation' or responsible autonomy polices may be used to minimise open expression of industrial conflicts. Responsible unionism strategy involves the attempt to harness adaptability of labour power by giving workers leeway and encouraging them to adapt to changing situations in a manner beneficial to the state. This is conceptually similar to what has been called managerial devices to enhance satisfaction that is usually achieved by giving workers status, authority and responsibility. Recent variant of this strategy is the appointment of labour leaders into Committees and Task Forces at the state level. For instance, by appointing labour leaders into the Committee on Privatisation and Commercialisation, PPPRB, and other bodies connected with State's Economic Reforms, labour is expected to behave responsibly, and serve as the explainers of state policies to their members; as well as the couriers of labour's demands to the State authorities.

The fourth quadrant represents the ultimate action that the State can use in State-labour relations. This involves deployment of strategic measures in reaction to strategic actions by labour. The perfect example is perhaps the multiplicity of federations of trade unions in 2004. As it became obvious that the NLC was gaining increasing strength as a result of dysfunctional federalism adopted in Nigeria, the State soon realised its vulnerability in the face of organisationally strong and financially viable Congress, with its avowed intent to pathologically constrain the achievement of state's economic reforms. Consequently, the thesis that the multiplicity of union centres was to break the hegemony of the NLC seems plausible. At any rate, this action illustrates the deployment of long-term strategy by the State to counter workers' long-term strategy. In other countries, it may be that the State acting in concert with employers severally or jointly embark upon covert actions to break such incipient organisations of workers.

The nature of industrial relations and the structuring of the stakeholders and the powers possessed by them in developing nations places the State in a position where it is better able to use strategic actions over labour's actions. In these countries the State's power is enhanced by alliance of some sorts between intricately intertwined state elites and moneyed interests. For instance, a State practice that had its roots in colonialism is to establish the presence of law enforcement agencies within various employers' premises, both private and public employers. Such permanent structures as a police post serves direct and indirect deterrence to the articulation, organisation and execution of organised workers actions. Consequently, from the standpoint of power relations, labour and the State are never two equal parties in industry. Labour formations on the other hand, are not usually equipped with the resource (human and material) to use in pre-empting and predicting the actions of the State. In effect, labour is only able to adopt strategic actions minimally.

The above treatment of actions and reactions are perhaps too simplistic in describing the rather complex issues of State-labour relations in society. Nevertheless, it enables a study of specific cases, inter-and intra-industry practices and cross-national comparisons.

\section{RESPONSE EFFECTIVENESS}

Against the backdrop of the foregoing dynamics, the responses of labour to current economic reforms have neither been tactical nor strategic; an admixture of both tactics and strategies as specified in the framework earlier explicated in Figure 1 have been applied. The fundamental aggravation of the conflict seems to be traceable to the perceived insufficiency of resources and endowments in the Nigerian society, causing strains and stresses on available resources and a 
desperation over the control of state resources. Individual workers would experience trauma trying to openly react to State tactics and strategies given the nature of social relations of production in capitalist settings. To every individually expressed form of conflict at work, the employer is able to deploy administrative disciplinary measures to control and correct deviant behaviour. Individual attempts at protesting foul state actions are thus usually not effective. However, in the continuous struggle for control over work relations and processes, the State has a sustained poise to articulating and engendering counter strategies to foil the (re)actions of organised labour over the issue of humanising current reforms, and to make such actions of labour ineffective.

\section{CONCLUDING REMARKS}

Reform ordinarily will seek to address weaknesses of a given system in order to strengthen it for better performance. In this light, reform is a necessity to address the damage done to the nation's political and socio-economic system. Change is a phenomenon that pervades everyday living. However, reform meant for the people must be people friendly to the extent that the hurt to the people must not skew to the extreme of the hardship continuum. Key elements to a people oriented change process are consultations and reduction of pains that such reforms may inflict on the people. Impulsive and hasty deployment of reform measures must be avoided, and reform options must be processed cautiously and diligently pilot-tested to avoid death on arrival of such policies, or discontinuance by succeeding administrations. This should be noted in the processing of future reforms.

The global choice of a development path is currently capitalism and liberalization. This is facilitative of the growth of the private sector. Consequently to achieve effective and people friendly reforms, the stakeholders must ensure a good balance between social justice and corporate competitiveness.

\section{References}

Agbon I S (1986) "Industrial Conflict and the Nigerian Petroleum Economy, 1976 - 84", Proceedings of the 4th Annual Conference of the Department of Industrial Relations and Personnel Management, University of Lagos, October.

Akinsanya A A (1984) Multinationals in a Developing Environment: A Study of Business-Government Relations in the Third World, Praeger, New York.

Alavi H (1972) "The State in Post-Colonial Societies", New Left Review, Vol. 74

Anderson P (1967) "The Limits and Possibilities of Trade Union Action" in Blackburn R M (1967), Union Character and Social Class, Batsford, London.

Bierstecker, T J (1987). Multinationals, the State and Control of the Nigerian Economy, Princeton University Press, New Jersey.

Braverman H (1974) Labour and Monopoly Capital, Monthly Review Press, New York.

Fajana Sola (1986) "Economic Challenges and the Changing Concerns of Actors in Nigeria's Industrial Relations", in Dietrich Schaupp and R. Elkin (Eds.) Proceedings of The 1986 Annual Conference of The Council On Employee Responsibilities and Rights, Pp147-154. Virginia Beach, Virginia: CERR.

Fajana, Sola (1999). “Understanding The Dialectics Of Labour-Management Relations And Effectiveness Of Workers' Collective Actions”, Nigerian Journal Of Industrial Relations, Vol 7, pp1-12.

Fajana, Sola. (2005a). Deregulation of Fuel Price: The Nigerian Experience, Conference of the Trade Union Congress of Ghana, May 20.

Fajana, Sola. (2005b). Industrial Relations in the Oil Sector in Nigeria, Working Paper Series. International Labour Organisation, Geneva.

Freund Bill (1981) Capital and Labour in Nigerian Tin Mines, Longman, Essex.

Gouldner A W (1954), Wildcat Strike, Harper and Row, New York 
Government of Nigeria (2008). Public Service Reform: Generic Guidelines for the Reform of Parastatals, Issued by the Bureau of Public Reforms, The Presidency

Government of Nigeria (2010). Federal Ministry of Education, unpublished report.

Hyman R (1972) Strikes Fontana Books, London.

Nelson, Jane and Dave Prescott (2003). Business and the Millenium Development Goals: A Framework for Action. www.globalcompact.org, UNDP.

Nigeria. Public Service Reform: Generic Guidelines for the Reform of Parataatals, Issued by the Bureau of Public Reforms, The Presidency.

NUC (2019). Website of the National Universities Commission

Ogbeifun, Brown (2004). Reform and the People, PENGASSAN website

Ojo, J A T (1995). Management of Small and Medium Scale Enterprises in Nigeria, Pumark Nigeria Limited, Lagos

Osigweh, C A B and Fajana, Sola (1993) "Economic Challenges and the Changing Concerns of Actors in the Industrial Relations System of Nigeria", Labour Studies Journal. West Virginia, USA. Vol 17, No 3, Pp51-72.

Uneke Chigozie Jesse et al.. (2017). An assessment of policymaker's engagement initiatives to promote evidence informed health policy making in Nigeria The Pan African Medical Journal - ISSN 1937-8688.

http://www.panafrican-med-journal.com/content/article/27/57/full

Uzochukwu Benjamin, Obinna Onwujekwe, Chinyere Mbachu, Chinenye Okwuosa, Enyi Etiaba, Monica E. Nyström \& Lucy Gilson (2016). The challenge of bridging the gap between researchers and policy makers: experiences of a Health Policy Research Group in engaging policy makers to support evidence informed policy making in Nigeria. Globalization and Health. Volume 12, Article number: 67 (2016)

Worldometers (2019). https://www.worldometers.info/world-population/visited 29 July 2019 